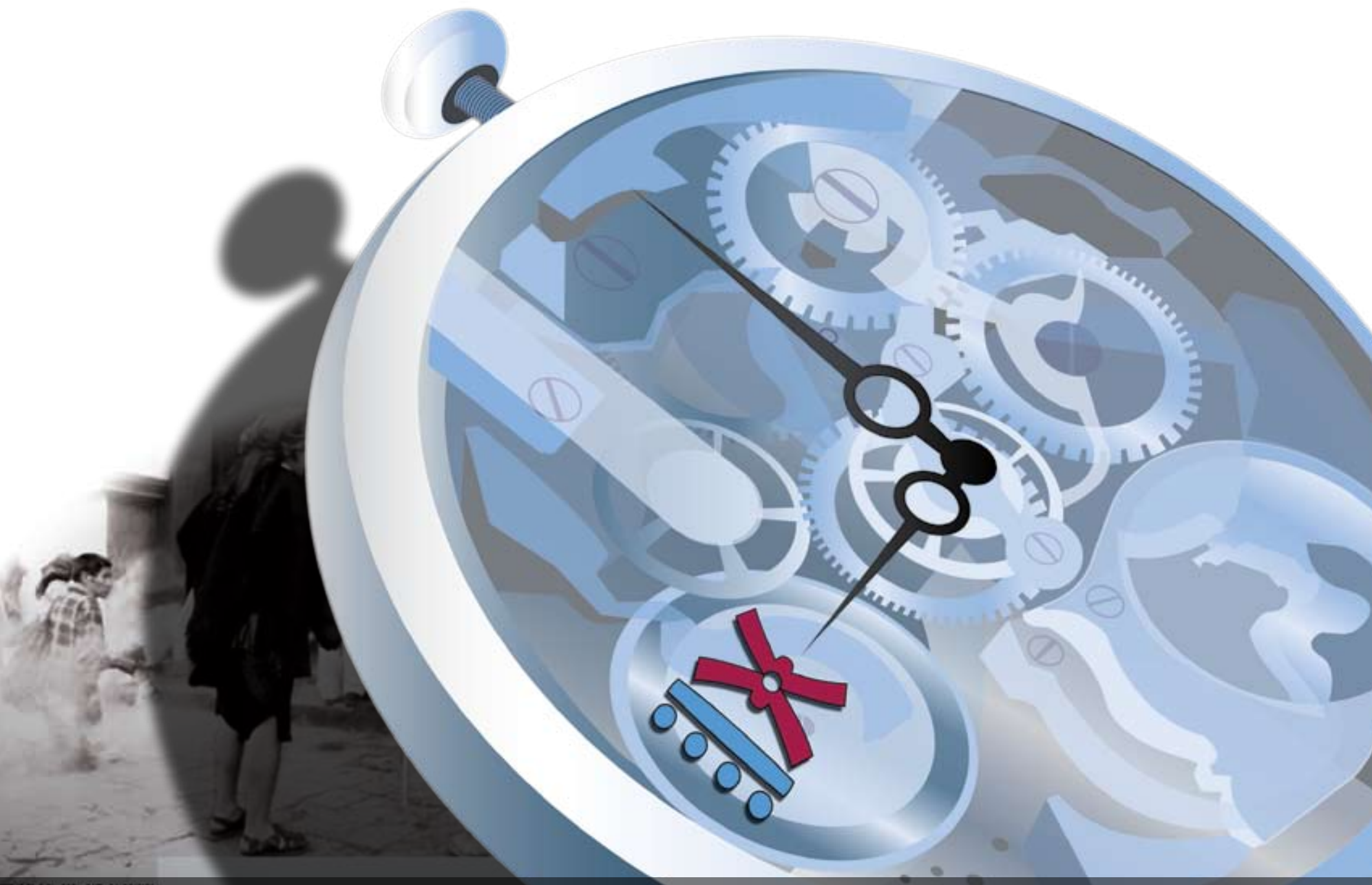

$9^{\circ}$ C O N G R E S O 2. CENTROAMERICANO DE H IS TOR I A
Universidad de Costa Rica

ISSN 1409- 469X

Fecha de recepción: 15 de mayo 2008 Fecha de aceptación: 30 de mayo 2008

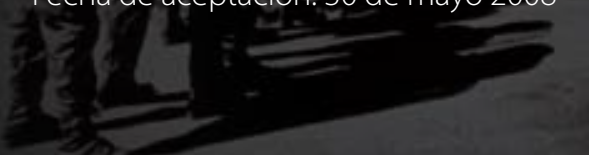

La epidemia del cólera (1856) en Costa Rica: una visión de largo plazo

Miembros del Consejo Editorial:

Dr. Ronny Viales, Dr. Juan José Marín

Editores Técnicos:

Allan Fonseca, Andrés Cruz, Gabriela Soto

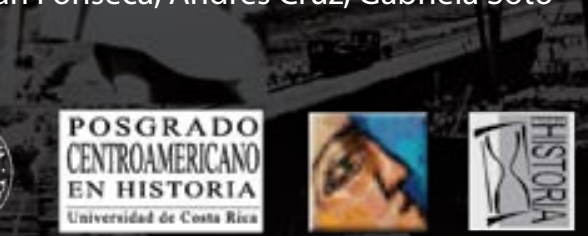


Indexaciones: Repositorio de Revistas UCR, DIALNET, Latindex, REDALYC Directorio y recolector de recursos digitales del Ministerio de Cultura de España, Directory of Open Access Journals. Diálogos Revista Electrónica de Historia ISSN 1409-469X. Número especial 2008. Dirección web: http://historia.fcs.ucr.ac.cr/dialogos.htm

\section{La epidemia del cólera (1856) en Costa Rica: una visión de largo plazo}

\section{Ana María Botey Sobrado}

Profesora de la Escuela de Historia e investigadora del Centro de Investigaciones Históricas de América Central de la Universidad de Costa Rica. abotey@gmail.com 


\section{Introducción}

El estudio de las epidemias, desde la óptica de la historia social y de la salud, en Costa Rica, apenas se inicia, aunque esta temática ha sido abordada ampliamente por los historiadores, en el ámbito europeo y latinoamericano, desde la década de $1960 .{ }^{1}$ Esta epidemia ha sido tratada por la historiografía costarricense, principalmente, como parte de los hechos históricos que integran la Campaña Nacional 1856-1857, en calidad de causa fundamental del retiro del ejército costarricense de suelo nicaragüense, sin haber derrotado militarmente a las tropas filibusteras, comandadas por William Walker. ${ }^{2}$

Las investigaciones históricas interesadas en la epidemia, propiamente, son pocas, la primera fue realizada por German $\operatorname{Tjars}^{3}$ y su equipo de estudiantes de la Escuela de Historia de la Universidad Nacional, con el propósito de conocer el impacto demográfico del cólera en el Valle Central y la segunda fue efectuada por el epidemiólogo Leonardo Mata, ${ }^{4}$ con el fin de desarrollar una historia epidemiológica del cólera en Costa Rica.

En esta ponencia sobre la epidemia del cólera en Costa Rica durante 1856 se investigan

$1 \quad$ El estudio de las epidemias, especialmente de las de cólera, llama la atención de los historiadores sociales en los inicios de la década de 1960: Charles Rosenberg (1959), Asa Briggs (1961) y Norman Longmate (1965). A fines de la década de 1980 se renueva el interés, bajo nuevos enfoques, en una serie de historiadores franceses: Pierre Guillaume, Patrice Bourdelasi, François Lebrun, Claude Quetel, Y Raulot, L Chevalier, Jean Pierre Bardet. En España, se han desarrollado diferentes estudios a partir de la década de 1990. Al respecto es importante el estado de la cuestión que se encuentra en: Serrallonga Urquidi, Joan "Epidemias e historia social. Apuntes sobre el cólera en España, 1833-1865” Historia social (España) 24, 1996, 7-21.

Armus, Diego "Legados y tendencias en la historiografía sobre la enfermedad en América latina moderna" Avatares de la medicalización en América Latina 1870- 1970. (1ª. Edición. Buenos Aires: Lugar Editorial, 2005) 18-20 Armus realiza un estado de la cuestión sobre la historiografía relativa a las enfermedades y señala que en torno a las epidemias es donde la historiografía latinoamericana ha sido más prolífica y presenta los rasgos más importantes de estos trabajos.

2 En esta línea sobresalen las obras de: Montúfar, Lorenzo Walker en Centroamérica. (Guatemala: Tipografía La Unión, 1887). Calvo Mora, Joaquín Bernardo La Campaña Nacional contra los filibusteros en 1856 y 1857. Breve reseña histórica. (San José: Tipografía Nacional, 1909). Obregón Loría Rafael, Costa Rica y la guerra contra los filibusteros. (Alajuela: Museo Histórico Cultural Juan Santamaría, 1991) (la última de sus obras relativa al tema). Meléndez Chaverri, Carlos. Juan Santamaría. Una aproximación crítica y documental. (Alajuela: Museo Histórico Cultural Juan Santamaría, Imprenta Nacional, 1982). Carl Hoffman. Viajes por Costa Rica. (San José: Ministerio de Cultura y Deportes, 1976), entre otras. Un estudio de la historiografía de la Campaña Nacional se encuentra en: Molina, Iván y Díaz David La Campaña Nacional (1856-1857): historiografia, literatura y memoria. (San José: Editorial de la Universidad de Costa Rica, 2007).

3 Tjarks, German et al "La epidemia del cólera de 1856 en el Valle Central: análisis y consecuencias”. Revista de Historia (Costa Rica) 3 (julio- diciembre, 1976):

4 Mata, Leonardo Cólera. Historia, prevención y control. (San José: Editorial de la Universidad Estatal a Distancia - Editorial de la Universidad de Costa Rica, 1992) 
las condiciones de vida de los costarricenses, las causas inmediatas, el desarrollo y algunas respuestas sociales e institucionales. Consideramos que el estudio de una epidemia, a mediados del siglo XIX, permite evaluar las condiciones económico- sociales, políticas y culturales de la sociedad. Comprender qué tipo de sociedad era y qué condiciones poseía para responder a los grandes embates propios de ese siglo. Las epidemias en general, y esta en particular, que se encuentra en relación con la guerra y lo inesperado, trastornan el modo de vida de los habitantes, exacerban las tensiones e intensifican el impacto de los problemas cotidianos. La epidemia, también provoca los más arraigados temores, especialmente en una sociedad mayoritariamente campesina, extremadamente dependiente de las fuerzas de la naturaleza y bajo el influjo ideológico de la Iglesia católica. En consecuencia, resulta interesante analizar las respuestas sociales e institucionales frente al colapso. ${ }^{5}$

El trabajo se divide en tres partes. La primera identifica las condiciones de salud pública de Costa Rica durante el período de estudio y los antecedentes relativos a las epidemias, en general, y al cólera morbus en particular. La segunda analiza las causas y el desarrollo de la epidemia. La tercera se detiene en los impactos y las respuestas institucionales y sociales, intentando enfatizar en aquellos elementos que se deben tomar en cuenta para el análisis de una mirada de largo plazo.

\section{Las condiciones de vida y salud de la población en la década de $\mathbf{1 8 5 0}$}

En la Costa Rica de mediados del siglo XIX el bosque y la vegetación natural eran predominantes en el paisaje. La población rondaba los 110 mil habitantes y se encontraba ubicada de preferencia en el Valle Central. La esperanza de vida al nacimiento se acercaba a los 28 años, lo que significa que la mortalidad era muy alta, especialmente entre los niños. ${ }^{6}$ En un análisis

$5 \quad$ La metodología del estudio de la epidemia, en lo fundamental, se basa en la propuesta planteada por Marcos Cueto. El regreso de las epidemias. Salud y sociedad en el Perú del siglo XX. Serie: Estudios Históricos 22 (Lima: Instituto de Estudios Peruanos Ediciones, 2000)19. También se toman en cuenta las observaciones metodológicas planteadas por Serrallonga, Urquidi Joan “Epidemias e historia social”, 7-24 y por Armus, Diego "Legados y tendencias en la historiografía”, 18-20. La importancia del estudio de los elementos religiosos nos lo ha sugerido el trabajo de Rodríguez, Dobles Esteban "Catástrofes y mentalidades. Las creencias religiosas ante la catástrofe en el occidente del Valle Central de Costa Rica 1799-1853. (Tesis de licenciatura en Historia, Universidad de Costa Rica, 2005) 1- 210.

$6 \quad$ Robles Arodys, "Patrones de población de Costa Rica 1860.1930” Avances de Investigación No.14 (Centro de Investigaciones Históricas, 1986). 
de largo plazo de la mortalidad, se ha calculado que para esa época la mortalidad de infantes y adolescentes en edad pre-conceptiva representaba el 633 por ciento y en algunas ocasiones alcanzaba el 715 por ciento de las muertes anuales. ${ }^{7}$

Cálculos realizados para 1866, una década después de nuestro año de estudio, señalan que solo el 59 por ciento de los recién nacidos alcanzaba a cumplir los 5 años de edad. Sin embargo, los niños que lograban hacerlo podían esperar morir a los 50 años, en lugar de los 30 años, de expectativa de vida, que tenían al momento de su nacimiento. ${ }^{8} \mathrm{El}$ costarricense de mediados del siglo XIX, que llegaba a vivir o sobrepasar los 70 años, formaba parte de un pequeño grupo cercano al 10 por ciento de la población. En consecuencia, el adulto mayor o anciano, como se denominaba en ese entonces, ocupaba un lugar importante en esa sociedad como símbolo de sabiduría y experiencia. También, el adolescente de esa época podía considerarse un sobreviviente, puesto que menos del 60 por ciento de su generación era capaz de llegar a esa etapa de la vida. ${ }^{9}$ Las principales causas de muerte se encontraban relacionadas con las enfermedades infecciosas e infectocontagiosas. ${ }^{10}$

Hacia 1856, las epidemias habían dejado sus huellas en el territorio, producto de la conquista española en el mundo americano. ${ }^{11}$ Los nuevos agentes patógenos ${ }^{12}$ traídos por los

7 Tjarks, German et al “La epidemia del cólera de 1856 en el Valle Central: análisis y consecuencias”. Revista de Historia (Costa Rica) 3 (julio- diciembre, 1976): 82.

8 Rosero, Luis La situación demográfica de Costa Rica. (San José: Asociación Demográfica Costarricense .Séptimo Seminario Nacional de Demografía, agosto, 1979) 8-14.

$9 \quad$ Ibíd., 18-19.

10 Lachner S., Vicente. “Apuntes de Higiene Pública 1800-1900”. Revista de Costa Rica en el siglo XIX. Tomo I (Costa Rica: Imprenta Nacional,1902) 189-190

11 El debate sobre las múltiples causas de la catástrofe demográfica en Hispanoamérica continúa vigente. Los investigadores difieren en el peso que le asignan a la propagación de las epidemias, todos concluyen en que estas no explican la totalidad del fenómeno, pero constituyen un elemento de gran importancia. Al respecto véase: Sánchez Albornoz, Nicolás “El debate inagotable” Revista de Indias (España) LXIII, n. 227: 9-18. Livi Bacci, Máximo "Las múltiples causas de la catástrofes: consideraciones teóricas y empíricas” Revista de Indias (España) LXIII, n. 227:31-48. Malvido, Elsa "La epidemiología, una propuesta para explicar la despoblación americana” Revista de Indias (España) LXIII, n.227:65-78.

12 Los nuevos agentes patógenos se pueden clasificar en varios grupos. En este caso interesa destacar el grupo de patología biológica: viruela, sarampión, tos ferina, varicela, paperas. Estos permiten a los sobrevivientes crear una memoria inmunológica en su organismo. El grupo de patología bio- social: como la peste en sus tres tipos: bubónica, neumónica y hemorrágica. No produce inmunidad ya que el causante de la enfermedad muta cada vez que se presenta. Estas patologías son de origen zoonótico-animal- pero humanizadas y domesticadas en el mundo no americano. En América eran desconocidas por la ausencia de los animales portadores, huéspedes y transmisores: vacas (viruela), gallinas (varicela), rata ratus (peste), rata Norvegicus (tifus) entre otras. Malvido, Elsa “La epidemiología, una propuesta para explicar.”:66-67. 
europeos a tierras americanas, continuaron domesticándose, en un proceso que se mantiene hasta la actualidad. Estos agentes, unidos a un conjunto de condiciones ambientales, económicosociales, políticas y culturales, han contribuido al desarrollo de múltiples brotes epidémicos, algunos de los cuales persisten hasta el presente, en diferentes regiones de América Latina.

Después de la independencia, la viruela una de las enfermedades contagiosas más temidas, afectó a los pobladores de la ciudad de Cartago en 1831 y en el transcurso de dos años se expandió por diversas partes del territorio, pese a que algunas poblaciones eran vacunadas, mediante la inoculación de fluido vacuno. Las fuentes revelan las deficiencias en su aplicación, lo que explica en parte, las resistencias de la población, el alcance limitado de estas y la presencia cíclica de la enfermedad. En 1845, se presentó una segunda epidemia que se localizó en el Pacífico Norte, concretamente en el Guanacaste, y la tercera epidemia de viruela, del período independiente, azotó al país en 1852, en todos los casos causando muchas pérdidas humanas y grandes trastornos sociales. ${ }^{13}$

En 1853, en el puerto de Puntarenas, principal puerto de Costa Rica en esa época, situado en el Pacífico, se presentó un caso de fiebre amarilla, atribuido a una persona que viajaba en un buque alemán. Posteriormente, apareció con recurrencia en la zona y en otras partes de Costa Rica. Todo indica que "las fiebres de Puntarenas", una enfermedad desarrollada por los arrieros que conducían las carretas al puerto, cargadas de café o mercaderías, constata la presencia de la fiebre amarilla, la cual luego se desplaza a ciudades del Valle Central. ${ }^{14}$

13 Lachner Vicente “Apuntes de Higiene Pública” 194-195. Rodríguez, Dobles Esteban “Catástrofes y mentalidades. Las creencias religiosas ante las catástrofes en el occidente del Valle Central de Costa Rica 17991853 (Tesis para obtener la licenciatura en Historia, Escuela de Historia, Universidad de Costa Rica, 2005) 126150 Falta un mayor estudio del impacto de esas epidemias.

14 Lachner, Vicente "Apuntes de Higiene Pública” 197-198.

La fiebre amarilla o vómito negro también llamada "plaga americana" es una zoonosis propia de algunas regiones tropicales de América del Sur y de África. Existen referencias históricas de la enfermedad desde hace varios siglos. Hay tres tipos de ciclos de transmisión: selvático, intermedio y urbano. En África se producen los tres, pero en Suramérica solo el selvático y el urbano. En el selvático, la enfermedad permanece en ciertas poblaciones de monos, quienes han sido infectados por mosquitos selváticos, pero que ellos transmiten a otros mosquitos que se alimentan de su sangre. Estos mosquitos infectados, luego pican a los humanos, generalmente trabajadores forestales y de esa forma realizan el ciclo de la enfermedad. El ciclo intermedio se produce en África en sabanas húmedas o semi húmedas, cuando mosquitos semi domesticados infectan a monos y a humanos. El ciclo urbano de transmisión se produce cuando viajeros de áreas rurales introducen el virus en poblaciones urbanas de alta densidad. Mosquitos domesticados, generalmente Aedes aegypti , transmisores del parásito, infectan a las personas. Estos se reproducen en aguas estancadas o charcos. http://www.who.int/csr/disease/yellowfev/en/index. html (Fecha de acceso: 28 de mayo 2008) "Variabilidad genética del virus de la fiebre amarilla en Brasil" Revista Panamericana de Salud Pública (Washington) 16, n.5 (2004):357, 358. 
Existen referencias documentales de la presencia del paludismo o malaria ${ }^{15}$ desde la época colonial, en diferentes regiones del territorio. En 1839, las autoridades políticas de Cartago y Heredia tomaron medidas para combatir una epidemia que denominaron “calenturas malignas”, lo que sugiere que se trataba del paludismo. En opinión del Dr. Vicente Lachner, en un trabajo realizado en 1900, la causa de esa epidemia se encontraba en "la suma humedad de un suelo esponjoso, suave, infeccionado en las ciudades por los residuos orgánicos y por las pésimas cañerías, y seguido a corta distancia por un subsuelo impermeable”. Sus observaciones demuestran que las concepciones miasmáticas continuaban en vigencia entre los médicos de inicios del siglo XX en Costa Rica y que estas se articulaban con la revolución bacteriológica, sin mayor problema. ${ }^{16}$

ElDr.Lachnertambién consigna queesas condiciones, unidas al efectodela descomposición de las mieles del café, lanzadas por los beneficios húmedos a los ríos y la mala calidad de las aguas de consumo humano, eran responsables de la disentería, una grave enfermedad infecciosa, que afectaba especialmente a los niños, entre los cuales ocasionaba altas tasas de mortalidad. ${ }^{17}$ Entre la población infantil eran comunes también otras enfermedades infecto- contagiosas tales

15 La malaria, el paludismo o las fiebres tercianas como se le conocía antiguamente en España, es una enfermedad causada por un parásito del género plasmodium, transmitido por el mosquito hembra del género Anopheles, mediante una picadura en la piel de los humanos y otras especies como pájaros, para alimentarse de sangre. Estos parásitos primero colonizan el hígado y luego invaden los glóbulos rojos. La malaria es una enfermedad de vieja data, que se produce en múltiples partes del mundo y afecta a muchos millones de personas, especialmente pobres. Los aumentos de la temperatura y los movimientos de población aumentan el riesgo de contraerla. http://www.who.int.malaria/aboutus.html (Fecha de acceso: 28 de abril 2008)

16 Lachner, Vicente“Apuntes de Higiene Pública”, 199. Caponi, Sandra "Trópicos, microbios, vectores” Historia, Ciencias, Saúde-Maguinhos (Río de Janeiro) 9, suplemento, 2002: 116-117.

17 La disentería es un término en el que se agrupan diferentes trastornos inflamatorios del intestino. Se puede distinguir entre disentería bacilar causada por diferentes bacterias como salmonella, shigella, E coli y la amebiana o amebiasis, causada por la ameba entamoeba histolytica. El vehículo de transmisión más común es el agua contaminada o el suelo fertilizado con desechos humanos sin tratar. Las cucarachas y las moscas también pueden propagar los quistes. La materia fecal de los humanos es el agente contaminador, ya que este parásito vive en los seres humanos, generalmente en el intestino grueso- colon-aunque puede extenderse a otros órganos. No causa infección en animales, tampoco son portadores del organismo. Es común en áreas con pésimas condiciones sanitarias. http://www.avera.org/avera/adam/5/000298.adam (Fecha de acceso:28 de abril 2008) 
como: la tos ferina, ${ }^{18}$ el sarampión, ${ }^{19}$ la influenza, ${ }^{20}$ la varicela, ${ }^{21}$ las paperas, ${ }^{22}$ la tifoidea, ${ }^{23}$ el cólera infantil, ${ }^{24}$ todas las cuales producían una alta mortalidad. ${ }^{25}$

El aislamiento de Costa Rica, especialmente de la Meseta Central, situada en el interior del país, donde se ubicaba la mayor parte de la población, en bajas densidades de población y las buenas condiciones ecológicas y climáticas, alabadas por los viajeros extranjeros, posibilitaron que el impacto de las epidemias que azotaban al mundo entero- cólera, viruela, fiebre amarilla, influenza- fuera relativamente leve, con excepción de la epidemia del cólera de 1856.

18 La tos ferina es una enfermedad infecto- contagiosa producida por un bacilo aerobio, como agente único o asociado a otros. Es un patógeno humano exclusivo. Se caracteriza por una tos paroxística típica en accesos. Corretger, Rauet “Tos ferina” http://www.aeped.es/protocolos/infectologia/35-Tosferina.pdf (Fecha de acceso: 28 de abril 2008)

19 El sarampión es una enfermedad altamente contagiosa producida por el virus paramyxovirus. La infección se transmite por medio de las gotitas que se expulsan por la nariz, la boca o la garganta infectada. Los afectados presentan fiebres, tos y conjuntivitis. Puede causar complicaciones graves como: neumonía, encefalitis, diarrea y ceguera. Es una enfermedad de humanos, no se conoce entre los animales. http://www.who.int/features/ qa/53/es/index.html (Fecha de acceso:29 de abril 2008) http://www.who.int/mediacentre/factsheets/fs286/en/ index.html (Fecha de acceso: 29 de abril 2008)

20 La influenza es una infección viral que afecta principalmente la nariz, la garganta, los bronquios y ocasionalmente los pulmones. Se transmite por vía aérea al inhalar gotitas secretadas por la nariz o la boca. La infección se expande muy rápidamente y puede llegar a provocar grandes epidemias. Puede producir severas complicaciones como la neumonía y conducir a la muerte. http://www.who.int/topics/influenza/en Fecha de acceso: 29 de abril 2008)

21 La varicela es una enfermedad infecto contagiosa producida por el virus varicela zoster, cuya transmisión se realiza en forma aérea, por contacto directo. Es muy contagiosa y típica de la infancia. En los climas templados presenta un patrón estacional característico, ya que su aparición ocurre durante el invierno y la primavera. El virus puede permanecer latente en los seres humanos. El riesgo de complicaciones se produce con la edad o durante el embarazo, ya que puede afectar al feto. El virus se desplaza al hígado, bazo, ganglios y finalmente a la piel produciendo erupción cutánea. Es una enfermedad de humanos. http://www.jccm.es/sanidad/ salud/promosalud/pdf/varicela2.pdf (Fecha de acceso: 29 de abril 2008)

22 La papera o paroditis epidémica es una enfermedad vírica aguda, el virus causante pertenece al grupo de los paramixovirus. Se transmite por vía aérea al inhalar pequeñas gotas infectadas, producidas al estornudar o toser. Sus síntomas son: fiebre, dolor de cabeza, inflamación de las glándulas. Puede producir serias complicaciones: meningitis, meningo encefalitis e inflamación del páncreas. http://www.who.int/vaccine_safety/ topics/mumps (Fecha de acceso: 29 de abril 2008)

23 Las fiebres tifoideas son causadas por el bacilo Typhi Salmonella. Se caracteriza por fiebre, fuertes dolores de cabeza, náuseas, pérdida del apetito, constipación y diarrea. Puede causar serias complicaciones como la meningitis. La enfermedad es producida por la ingesta de alimentos y agua contaminada por heces u orina de personas que la portan. El agua contaminada es la principal fuente de contagio. Las personas portadoras pueden transmitir la bacteria mientras la conserven en su organismo. http://www.who.int/vaccine_research/diseases/ diarrhoeal/en/index7.html (Fecha de consulta: 29 de abril 2008)

24 Cólera infantil se denominaba en la época a un conjunto de diarreas infantiles, de origen gastrointestinal producidas por diferentes bacterias o virus. Muchas veces por el consumo de agua contaminada.

25 Lachner, Vicente “Apuntes de Higiene Pública” 199-200. 
Desde el punto de vista de la salud, el principal enemigo de la población, especialmente de la infantil, estuvo siempre en las enfermedades infecto- contagiosas, provocadas por la contaminación de las aguas, la carencia de infraestructura sanitaria y el desconocimiento de las normas de higiene. Estas enfermedades, producto de condiciones internas, fueron las que ocasionaron estragos entre la población, hasta la primera mitad del siglo XX. ${ }^{26}$

La lepra, una enfermedad contagiosa pero no epidémica, con presencia en el Valle Central desde el período colonial, fue sin embargo, la que concentró la atención de las autoridades y la que condujo a la creación de la primera institución de carácter "sanitario”, el Lazareto General del Estado de Costa Rica en 1833. ${ }^{27}$ Las huellas físicas de la enfermedad, provocaban un profundo temor y estigma y la respuesta de la sociedad, desde el período colonial, en América, consistió en aislar e institucionalizar a las personas que se creía enfermas ${ }^{28}$. La sífilis, a menudo confundida con la lepra, fue también una enfermedad controversial en términos más morales que relacionados con la salud, pese a no poseer tampoco, carácter epidémico. ${ }^{29}$ Las enfermedades venéreas eran muy temidas entre la población debido a que no se conocía un tratamiento efectivo, los que se usaban eran inútiles y dolorosos. La sífilis, como ha señalado el historiador Juan José Marín, en un contexto de predominio de explicaciones religiosas, de la cultura herbolaria y familiar, era relacionada con males de ojo, maleficios, y otros castigos divinos. ${ }^{30}$

Desde el período colonial, siguiendo el ejemplo de las directrices que las autoridades europeas y españolas ordenaban y ponían en práctica cuando se presentaban las epidemias, se tomaron medidas para mitigar los efectos de estas. ${ }^{31}$ Algunas de las más importantes consistieron en la prohibición de desembarque de marineros, pasajeros y objetos provenientes de lugares donde había hecho su presencia una enfermedad epidémica, así como el establecimiento de cuarentenas y cordones sanitarios, "hechos a medias", en opinión del doctor Vicente Lachner, tanto en las fronteras, como en los puertos y los focos infecciosos. ${ }^{32}$ Las autoridades también $26 \quad$ Ibid., 190.

27 Véase al respecto: Malavassi, Ana Paulina. Entre la marginalidad social y los orígenes de la salud pública. (San José: Editorial de la Universidad de Costa Rica, 2003) 53-69.

28 En esa época la lepra era confundida con muchas otras enfermedades dermatológicas y de otra índole, incluso por los médicos, debido al poco desarrollo de la medicina y la falta de instrumentos de diagnóstico.

29 Ibíd., 145.

30 Marín, Juan José. La tierra del pecado, entre la quimera y el anhelo: historia de la prostitución en Costa Rica, 1750-2005. (San José: Editorial Librería Alma Mater y Editorial Sociedad Nueva Cultura, 2006), 80-81.

31 Véase al respecto el esclarecedor trabajo de: Betrán Moya, José Luis Historia de las epidemias en España y sus colonias (1348-1919) (Madrid:La Esfera de los libros, 2006)

32 Lachner, Vicente “Apuntes de Higiene Pública”, 201. 
giraban instrucciones orientadas a mantener el aseo en los pueblos y en las casas y divulgaban formas de tratar la enfermedad. No obstante, debido al poco desarrollo de la infraestructura sanitaria, la medicina y la farmacéutica, la mayoría de los tratamientos eran poco eficaces.

En ese mundo del siglo XIX, la muerte era tan frecuente, que algunos viajeros alemanes expresaron que "a los costarricenses no les gusta hablar de la muerte y no quieren pensar en ella”. ${ }^{33}$ La muerte se consideraba un fenómeno cotidiano, ineludible, que cuando ocurría en niños se celebraba, mediante la "vela del angelito", un espacio de sociabilidad, donde los parientes charlaban, comían, tomaban licores y ponches, sin la menor huella de dolor, para extrañeza de los ojos extranjeros.

La infraestructura sanitaria de la época era sumamente deficiente, lo que explica las graves consecuencias de las enfermedades infectocontagiosas en la población, especialmente la infantil. Las pequeñas ciudades de Cartago, San José, Heredia y Alajuela habían sido construidas a una distancia prudente de los ríos, buscando las zonas menos húmedas, por lo que el agua de uso diario era llevada a las viviendas por largas zanjas o acequias, una especie de canales abiertos, los cuales arrastraban impurezas hasta llegar a su destino. En consecuencia, el agua se transformaba en un medio de contaminación y propagación de enfermedades, era sucia y a veces con un olor insoportable, por la descomposición de todo tipo de materias. Para obtener agua potable se acostumbraba, especialmente en las casas de mayores recursos, filtrarla por medio de una pila de piedra esponjosa. ${ }^{34}$

Un relato sobre la vida en Cartago y San José durante el siglo XIX nos permite imaginar la forma en que la gente se abastecía de agua y descubrir ¿quiénes eran las familias "más aseadas"? ${ }^{35}$

"No había cañería; el agua se tomaba, para todos los usos, de una acequia o atarjea ${ }^{36}$ bien distribuida por toda la ciudad y en algunas casas había pozos y las familias más aseadas traían el precioso líquido de una fuente cercana. Se creía que recogiendo el agua temprano, se encontraba limpia para llenar la tinaja de barro o la destiladera de piedra.”.

33 Wagner, Moritz y Scherzer, Carl. La República de Costa Rica en Centro América. (San José: 1941) 127. Tomado de: Tjarks, German et al "La epidemia del cólera”, 81-83.

34 Lachner, Vicente “Apuntes de Higiene Pública”, 209-210

35 Echeverría Aguilar Manuel "La vida patriarcal hace sesenta años en esta capital y en Cartago" Álbum de Granados, tomo V, pág. 23-24. Tomado de: La vida cotidiana de nuestros abuelos (1801-1910) Crónicas Compilación de Elías Zeledón Cartín. (San José: Editorial Costa Rica, 2004) 208.

36 Atarjea: caja de ladrillo con que se protegen las acequias. 
El proyecto para construir una cañería en San José, la ciudad capital, se inició en la década de Mora Porras (1849-1959), sin embargo, por diversas razones, entre ellas el esfuerzo de la guerra contra los filibusteros y la consiguiente crisis fiscal, se paralizó hasta 1865, cuando volvió a resurgir. ${ }^{37}$ En las otras capitales de provincia, las cañerías se construyeron en el último tercio del siglo XIX, en las villas y pueblos debieron esperar al siglo XX para contar con ellas.

Las zanjas o acequias también servían, en los poblados que las construían, para desaguar las aguas pluviales, servidas y negras, por lo que la eliminación de estas aguas era muy imperfecta, ya que no existían las cloacas. Su necesidad fue evidente después de la construcción de las cañerías. En la mayoría de los caseríos rurales las personas buscaban habitar cerca de los ríos para obtener agua, mediante el acarreo manual, para las diferentes necesidades. El lavado de ropas y del cuerpo se realizaba en los ríos. Los ríos eran los receptores de todo tipo de desechos y aguas.

En cuanto a la construcción de las casas, el Dr. Vicente Lachner expresa que debido a la humedad del suelo, provocada por la abundante lluvia y vegetación, era importante que la vivienda se edificara a una altura cercana a un metro, sobre el nivel de la calle, o del lugar donde se emplazaba, con el fin de levantarla sobre unos cimientos rellenos de piedra, de cascajo y arena, encima de los cuales se colocaba un pavimento de ladrillo. Este sistema se denominaba de "casas henchidas" y era muy efectivo para combatir la humedad. No obstante, no se encontraba al alcance de toda la población. Molina, investigando la vivienda y el mobiliario en el Valle Central durante la coyuntura de la independencia (1821-1824), considera que el espacio urbano era más aldeano que citadino, una observación que para los años en estudio ya no se aplica para la capital y las cabeceras de provincias del Valle Central, pero que era válida para las villas y pueblos. En ese entorno, las viviendas de los campesinos pequeños y los jornaleros eran pequeñas, carecían de puertas y ventanas, ya que estas tenían un alto costo, se encontraban poco aireadas e iluminadas, lo que favorecía el desarrollo de las enfermedades contagiosas. ${ }^{38}$

Los servicios sanitarios no eran de uso común, cuando estos existían eran simples fosas cavadas en el suelo, donde se depositaban las materias fecales hasta que el hueco se llenaba.

37 Decreto XXXIII (1857) Oficial, Colección de las Leyes Decreto y Ordenes expedidas por los Supremos Poderes Legislativo y Ejecutivo de Costa Rica en los años de 1856 y 1857.(San José: Imprenta de la Paz), 144145.

38 Molina Jiménez, Iván "Vivienda y muebles. El marco material de la vida doméstica en el Valle Central de Costa Rica(1821-1824) Avances de Investigación Centro de Investigaciones Históricas, Universidad de Costa Rica (Costa Rica) 65, 1993, 5 y 6. 
Entonces, se procedía a cegar el excusado con tierra y a abrir otro en un espacio cercano. Las normas de higiene personal, no solamente eran desconocidas para la población, como lo refleja el texto a continuación, sino que eran imposibles de practicar debido a la carencia de infraestructura sanitaria. ${ }^{39}$

“Solo se padecía de pasmo, de anasarca o de alferecía y las gentes morían de viejas y de los cuarenta años en adelante, nadie se bañaba. El refrán decía: “De cuarenta años para arriba, no mojes la barriga" o "Más vale tierra en cuerpo que cuerpo en tierra". ${ }^{40}$

Los mataderos públicos para el destace del ganado eran absolutamente rudimentarios y carentes de normas higiénicas, consistían en un galerón abierto por los cuatro costados, tanto en las pequeñas ciudades como en los pueblos. Por supuesto, no contaban con espacios apropiados para el destace del ganado. Asimismo, las ventas de carne, se realizaban al aire libre, desprovistas de lo necesario para la conservación de la carne en condiciones higiénicas, debido a la inexistencia de la refrigeración. ${ }^{41}$

El cuido de la salud dependía de las mujeres, en general, ellas ocupaban parte de su solar con la siembra de hierbas curativas. Las parteras, los curanderos y herbolarios, muchos de los cuales también eran mujeres, gozaban de gran prestigio en sus comunidades. ${ }^{42}$ Una pequeña comunidad médica y alguna infraestructura sanitaria debió esperar hasta la década de 1830, cuando producto del auge minero y el despegue cafetalero, llegaron a Costa Rica algunos médicos procedentes de diferentes partes de América, Europa y algunos hijos de la burguesía agro exportadora comenzaron a viajar al viejo continente a formarse en la profesión médica.

La escasez de recursos estatales, sumado al concepto y la mala percepción que se tenía en la época sobre los hospitales, contribuyeron a que estas instituciones surgieran en forma tardía. En 1833, se creó la primera de ellas: el Lazareto, mencionado con anterioridad, destinado

$39 \quad$ Lachner, Vicente “Apuntes de higiene pública” 213.

40 Echeverría Aguilar Manuel "La vida patriarcal hace sesenta años en esta capital y en Cartago" Álbum de Granados, tomo V, pág. 23-24. En: La vida cotidiana de nuestros abuelos (1801-1910) Crónicas Compilación de Elías Zeledón Cartín. (San José: Editorial Costa Rica, 2004) 208. Obsérvese que el narrador consideraba que las personas morían de viejas, lo que no era del todo cierto, solo se aplicaba a los que habían logrado sobrevivir a todas las enfermedades. Sin embargo, es interesante el reconocimiento de que a los 40 años las personas no se bañaban, o sea a partir de esa edad, se consideraba que las personas eran mayores.

$41 \quad$ Ibid., 213.

42 Marín, Juan José. “De curanderos a médicos. Una aproximación a la historia social de la medicina en Costa Rica: 1800-1949”. Revista de Historia (Costa Rica) 32 (julio- diciembre, 1995): 72-76. Malavassi, Ana Paulina Entre la marginalidad social y los origenes de la salubridad pública: leprosos, curanderos y facultativos en el Valle Central de Costa Rica. (San José: Editorial de la Universidad de Costa Rica, 2005) 
a recluir a los leprosos que deambulaban por los caminos, a quienes se les declaraba la "muerte social”. ${ }^{43}$ Sobresale el establecimiento de una policía de higiene en 1836 y la integración de Juntas de Sanidad y de Higiene a nivel provincial y local con el objeto de contener los efectos de las epidemias, siguiendo el modelo aplicado en España e Hispanoamérica colonial. ${ }^{44}$

El establecimiento de un Hospital General, un proyecto iniciado en varias oportunidades por personas vinculadas a la Iglesia, debió esperar hasta 1845, cuando el Dr. José María Castro Madríz, siendo presidente de la Cámara de Representantes, en el gobierno del Jefe de Estado José Rafael de Gallegos, logró el apoyo de los diputados para la creación de un hospital en San José, junto a un cementerio general y una Junta de Caridad encargada de la administración de ambos. ${ }^{45}$ Se nombró presidente de la Junta al Dr. Nazario Toledo, médico nacido en Guatemala. Debido a la falta de recursos económicos, en 1852, no se había iniciado su construcción.

Durante la década de Juan Mora Porras (1849-1859), se tomaron medidas para la pronta construcción de dos hospitales: el de la capital y el del puerto de Puntarenas. Para finiquitar la construcción del San Juan de Dios se propició la colaboración de la Iglesia Católica con el fin de obtener el apoyo de los habitantes, siempre dispuestos a cumplir las instrucciones de los sacerdotes. El gobierno designó a Anselmo Llorente y Lafuente, primer obispo de Costa Rica, como protector del Hospital General. Tres años después el edificio estaba concluido, pero el obispo Llorente presentó su renuncia al Congreso como Presidente de la Junta de Caridad, debido a que no estaba de acuerdo en que parte del Hospital se hubiera transformado en cárcel y asilo para "dementes" ${ }^{46}$ El Hospital San Juan de Dios demostró su utilidad durante la Campaña Nacional 1856-57.

En 1852, un decreto ejecutivo estableció la "urgente” creación del Hospital en el puerto de Puntarenas, con el fin de contribuir a mejorar la salud de diferentes tipos de usuarios: los habitantes del lugar, los arrieros y carreteros que concurrían desde el interior, las tripulaciones y pasajeros de los barcos, potenciales portadores de enfermedades provenientes del "exterior". El decreto estableció sus rentas y su futura denominación: San Rafael, para que estuviera bajo los 43 Malavassi, Ana Paulina Entre la marginalidad social ,62.

44 Ortiz, Bienvenido, Compilación de Leyes, Decretos y Circulares referentes a medicina e higiene del año 1821 hasta 1920. (San José: Imprenta Nacional, 1921)142. Tomado de Juan José Marín,” De curanderos a médicos”, 77.

45 Mentor Costarricense, 5 de julio de 1845, 365. Tomado de: Incera Olivas, Eugenia. "El Hospital San Juan de Dios sus antecedentes y su evolución histórica 1845-1900”. (Tesis para obtener la licenciatura en Historia, Universidad de Costa Rica, 1978) 109-111.

$46 \quad$ Ibid., 26-28. 
auspicios de este arcángel. ${ }^{47}$ Un hospital en Puntarenas constituía un esfuerzo importante en la lucha contra las enfermedades epidémicas, ya que se consideraba que los puertos eran los focos iniciales de contagio, por medio de las personas y mercaderías contaminadas. Sin embargo, no se relacionaba la propagación de las enfermedades con las condiciones sanitarias infraestructurales de los pueblos y ciudades. La construcción y administración de cementerios ocurrió paralela a la de hospitales, constituían su necesario complemento, debido a la alta mortalidad en los segundos y para disciplinar a los habitantes en prácticas mortuorias consideradas higiénicas en la época. Los cementerios estaban bajo la responsabilidad de la Iglesia, por lo que las medidas tendientes a regularlos siempre encontraron oposición entre la gente del pueblo y algunos miembros del clero. A fines de la época colonial, los gobernadores iniciaron la lucha contra la vieja costumbre de enterrar a los vecinos principales y a los curas dentro de las iglesias, o contiguo a estas, por razones de salud. Se establecieron disposiciones para su traslado fuera de las ciudades ${ }^{48}$ En 1828, se prohibió realizar velorios en las casas o en las iglesias y se dispuso que el cementerio de cada pueblo contara con una capilla de velación para ese efecto. Sin embargo, esta última medida no se logró cumplir y ejecutar. El primer cementerio a cargo de una Junta de Caridad fue el de San José en 1845.

En 1847, se estableció la figura de los Médicos de Pueblo, a cargo de los municipios, en cada provincia y comarca, es decir un total de 7 para todo el país, cuya función era velar por la higiene, una tarea fundamental para evitar las epidemias, realizar las vacunaciones contra la viruela y atender gratuitamente a los enfermos declarados pobres. Tres años después, el Congreso de la República estableció que en las ciudades, donde existiera un Médico de Pueblo este debía asumir los asuntos de medicina legal, y en caso de que no lo hubiere, sería sustituido por "un profesor de medicina” o por “dos empíricos”. ${ }^{49}$ No obstante, este decreto no se llevó a la práctica en su totalidad, por la carencia de fondos de los municipios, entes encargados de financiarlos y por la existencia de pocos médicos, todos los cuales se concentraban en San José, la capital. ${ }^{50}$

47 Decreto No. 52,14 de marzo de 1852. Oficial, Colección de las Leyes Decreto y Ordenes expedidos por los Supremos Poderes Legislativo y Ejecutivo de Costa Rica en los años 1854 y 1855 (San José, Imprenta de la Paz) 126-129.

48 Marín, Juan José “De curanderos a médicos”, 68-70.

49 Decreto No. 24, 28 de julio de 1851. Oficial. Colección de Leyes Decretos y Órdenes expedidas por los Supremos Poderes Legislativo y Ejecutivo de Costa Rica. (San José: Imprenta de la Paz) 46-47.

50 Malavassi, Ana Paulina Entre la marginalidad social, 160 


\section{La epidemia del cólera - 1856- Antecedentes}

La palabra epidemia, según su origen etimológico, proviene de las raíces griegas "epi” que significa sobre y "demos" pueblo. Se refiere a una enfermedad que se propaga durante algún tiempo, por una región o país y que afecta, simultáneamente, a un grupo de personas. ${ }^{51} \mathrm{Se}$ diferencia de la pandemia, palabra que también proviene del griego, en que esta describe una enfermedad epidémica que se extiende a muchos países o que ataca a casi todos los individuos de una región o localidad. ${ }^{52}$ Los epidemiólogos conciben a la epidemia como una enfermedad o fenómeno que aparece en un sociedad, en forma inusual, sin que antes estuviese presente, o si ya existía, en un exceso notable por sobre su nivel usual o endémico..$^{53} \mathrm{Si}$ el aumento se reduce a una localidad o a un grupo de familias se denomina brote epidémico. ${ }^{54}$

La primera evidencia de la existencia del bacilo del cólera en el mundo occidental se efectuó en 1503, producto del incremento del comercio marítimo entre continentes, una empresa liderada por los europeos en su afán de establecer y controlar un mercado mundial. Las pandemias de cólera fueron favorecidas por la comunicación marítima y las redes comerciales. Estas tuvieron como punto de origen, la mayoría de las veces, las ciudades de Goa y Bengala en la India, muy visitadas por comerciantes y aventureros. Desde principios del siglo XIX hasta fines del siglo XX se han desarrollado siete pandemias. La segunda pandemia ocurrió en 1829, se originó en la India y las actividades comerciales contribuyeron a su propagación por diferentes regiones del mundo, en los años posteriores. Entre 1836 y 1837 el cólera impactó México, Guatemala, Nicaragua y Panamá. En 1837, el gobierno costarricense emitió siete decretos, en los que se tomaban medidas preventivas para una eventual epidemia de cólera. Los decretos revelan las concepciones de la época sobre el origen de las enfermedades, las que se apoyaban en la teoría de los miasmas..$^{55}$

$51 \quad$ http://buscon.rae.es/draeI (Fecha de consulta: 29 de abril 2008)

$52 \quad$ http://buscon.rae.es/draeI (Fecha de consulta: 29 de abril 2008)

53 Las enfermedades endémicas son aquellas que habitan o reinan en determinadas épocas en una localidad o región. http://buscon.rae.es/draeI (Fecha de consulta: 29 de abril 2008)

54 Mata, Leonardo Cólera. Historia, prevención y control. (San José: Editorial de la Universidad Estatal a Distancia - Editorial de la Universidad de Costa Rica, 1992) 5

55 Decretos del 14 de mayo, 16 de junio y 2 de agosto de 1837. Gobierno de Costa Rica, Colección de Leyes y Decretos expedidos por los Supremos Poderes Legislativo, Conservador y Ejecutivo de Costa Rica, en los años 1837 y 1838. (San José: Imprenta de La Paz, 1859) 296 Tomado de Mata, Leonardo, Cólera. Historia, prevención y control, 49-51. 
En consecuencia, estas mismas medidas fueron las que se pusieron en vigencia en 1856, solo que a posteriori, porque el cólera, en esa oportunidad, tomó de sorpresa al ejército, a las autoridades y al pueblo costarricense. Se orientaban a que las personas y las autoridades realizaran acopio de alimentos y medicinas, como el láudano y el aceite, para combatir la enfermedad. Se instruía sobre la higiene personal, el aseo de los alimentos, las habitaciones, los patios, las acequias, las aceras, las calles y los acueductos de la comunidad. La preocupación básica era no infectar el aire y también evitar la “corrupción o humedad”. La fumigación de las casas debía efectuarse con agua de cal, tabaco en hoja o en vena, vinagre, sal marina o azufre. Los muebles tenían que limpiarse dos veces por semana con cloruro o cal viva. Se llamaba a evitar las aglomeraciones. En caso de que el cólera se hiciera presente, se prohibía la asistencia a las iglesias, solo se autorizaban las misas en las plazas o utilizando un altar portátil. También se previó el cierre de los mercados. Se prohibió la venta de chichas y caldos fermentados, verduras, frutas y carne añeja, así como colgar las perchas de carnes con el objeto de venderlas o asolearlas.

La policía era la encargada de que los sepultureros demarcaran el sitio para las excavaciones pertinentes, cuidando que fuera en tierra virgen, no menor a dos varas de profundidad. Los cadáveres, según las instrucciones, debían bañarse con cal viva antes de sepultarlos, junto a las ropas que se llevaban puestas. En caso contrario se exponían a castigos, multas y cárcel. Para disminuir el contacto con los enfermos y cadáveres, las ceremonias fúnebres y los entierros solemnes quedaban prohibidos. Como se comprenderá este conjunto de medidas, especialmente las que tenían que ver con la asistencia a iglesias y el entierro de personas, provocaban grandes resistencias entre la población debido a las concepciones religiosas imperantes.

El gobierno delegó la responsabilidad de la prevención y el control de la epidemia, en 1837, en una Junta General de Sanidad integrada por el licenciado en medicina Nazario Toledo, Agustín Gutiérrez, el general Pedro Bermúdez, Joaquín Mora, Mariano Montealegre, Miguel Carranza y el cura párroco de San José. Todos ellos personajes de la elite y del alto clero, tal y como se acostumbraba integrar estas juntas. Se dispuso el establecimiento de una "botica general" financiada por el gobierno para contar con las medicinas que se iban a necesitar, la cual quedó a cargo de Nazario Toledo.

El gobierno estableció en San José “una Cátedra de instrucción sobre el método preservativo y curativo del cólera-morbo" para adiestrar a "seis jóvenes de esa ciudad”, seis 
de Cartago, cuatro de Heredia, cuatro de Alajuela y cuatro de Nicoya, así como para los que estuvieran interesados en asistir. Entre los requisitos que se solicitaban para ser admitidos era que supieran leer y escribir, “alguna inclinación” suponemos que por la medicina, valor y presencia de ánimo, y tener entre dieciocho y treinta años de edad.

En esa ocasión, el cordón sanitario se trazó en las inmediaciones del límite con Nicaragua, el cual fue resguardado con guardias militares con el fin de impedir la entrada de personas. En Puntarenas, se emplazó una guardia para controlar el desembarco de personas y mercaderías procedentes de lugares donde se hubiera presentado el cólera. En caso de que los barcos arribaran serían enviados a la isla de San Lucas a guardar cuarentena. También se promulgaron serias sanciones para quienes se abstuvieran de denunciar el ingreso de personas y para quienes ingresaran violentando el cordón sanitario. ${ }^{56}$ En consecuencia, las medidas sanitarias de la época, eran de carácter autoritario y su violación constituía un delito.

No podemos determinar cuánta difusión tuvieron este conjunto de medidas, promulgadas por escrito, sobre una población que mayoritariamente no sabía leer ni escribir, aunque era común en esa época, que las autoridades locales divulgaran oralmente las disposiciones y que los sacerdotes, desde los púlpitos alertaran a la población. En esa oportunidad (1837) el cólera no penetró en territorio costarricense, sino que se detuvo en Nicaragua.

Un antecedente importante a considerar, por los efectos sobre los soldados costarricenses, constituye la presencia del cólera en Nicaragua durante 1854 y $1855,{ }^{57}$ ya que esto se tradujo en la obtención de cierta inmunidad a la enfermedad por parte de sus habitantes. En esos años, algunos pobladores de Granada y Rivas emigraron a territorio costarricense, donde el general José María Cañas estableció una estación provisoria de cuarentena en las haciendas de Sapoá y Las Ánimas, en cumplimiento del decreto del 2 de noviembre de 1855. Dos semanas más tarde, teniendo información de que no se habían presentado más casos de cólera, Cañas ordenó levantar el cordón sanitario y permitió que los inmigrantes se establecieran en cualquier punto de lo que hoy constituye la provincia del Guanacaste, previa inscripción en la oficina de Gobernación local. ${ }^{58}$

$56 \quad$ Oficial, Colección de Leyes y Decretos, Decretos XII, XIII, XIV, XV, XVI del 14 de mayo y decretos XVIII y XIX del 16 de junio y 2 de agosto de 1837. Tomado de Mata, Leonardo, Cólera, Historia, prevención y control, 53-55.

57 Carta de Rudesindo Guardia al ministro de Gobernación, del 26 de junio de 1855, donde le notifica que el cólera ha causado estragos en San Juan del Norte, Rivas y San Juan del Sur. Le consulta sobre la puesta en práctica de un cordón sanitario y las medidas de salubridad a considerar. ANCR Gobernación 28205, 1855, fs. 2324

58 Cabezas, Edgar La medicina en Costa Rica hasta 1900.( San José: EDNASSS,1990) 206-207 


\section{La epidemia del cólera (1856)}

\section{La marcha del Ejército Nacional hacia el encuentro de los filibusteros}

La amenaza filibustera obligó al ejército costarricense a enrumbarse a Nicaragua el 4 de marzo de 1856. Cerca de tres mil soldados ${ }^{59}$ emprendieron la marcha desde la plaza de la Catedral, divididos en tres regimientos: infantería, caballería y artillería, acompañados por el cuerpo médico, cuatro capellanes, una banda militar, mujeres de extracción popular en condición de cocineras, cantineras ${ }^{60} \mathrm{y}$ una interminable fila de carretas cargadas de municiones, sacos de comida, medicinas y otros. ${ }^{61}$

El 20 de marzo se efectuó la histórica batalla de Santa Rosa, la cual fue considerada un triunfo por las fuerzas costarricenses, puesto que los filibusteros debieron huir entre los montes y abandonar la hacienda Santa Rosa, ubicada en territorio nacional. El 10 de abril una columna integrada por alajuelenses se enfrentó a los filibusteros en la batalla de Sardinal, en la confluencia de ese río con el río Sarapiquí, en la cual no logró un triunfo definitivo, y el 11 de abril el ejército libró la batalla de Rivas. El ejército había llegado a Rivas el 8 de abril, las tropas se distribuyeron en varias casas grandes, al igual que el Estado Mayor, con el presidente Mora a la cabeza. ${ }^{62}$

El 9 de abril William Walker, quien se encontraba en León, decidió atacar a los costarricenses por sorpresa, por lo que se puso en camino hacia Rivas. El 11 de abril ingresó en la ciudad con sus tropas y aunque Mora había sido alertado de la presencia filibustera en los alrededores, la noticia no logró ser comprobada plenamente. La batalla del 11 de abril fue muy cruenta, Víctor Guardia y el Dr. Andrés Sáenz señalaron que en ella murieron quinientos soldados y trescientos resultaron heridos, de una tropa compuesta por mil novecientos soldados. No obstante, en el parte oficial emitido por el presidente Mora se reportó la muerte de ciento diez y en el libro de defunciones del padre Francisco Calvo, capellán del ejército, se consignó la cantidad de ciento treinta y seis soldados muertos. Es posible que el padre Calvo, debido al intenso trabajo de esos días atendiendo a los moribundos, haya escrito su libro al regreso a San José, y en sus cifras se encuentre un sub registro importante. ${ }^{63}$

59 En la carta del Ejército costarricense dirigida al presidente municipal de Rivas el 8 de abril de 1856, se argumenta que cuatro mil soldados costarricenses han venido a ayudarles a expulsar a los filibusteros. Boletín Oficial, 19 de abril de 1856, p1.

60 Molina, Iván La Campaña Nacional 1856-1857. Una visión desde el siglo XXI. (Alajuela: Museo Histórico Cultural Juan Santamaría, 2000) 71-72.

61 Arias, Raúl Médicos y cirujanos en la historia de Costa Rica. De la colonia al liberalismo.( San José, Ministerio de Salud, 1998.) 178.

62 Obregón, Rafael. Costa Rica y la guerra, 73-116

63 Arias, Raúl, Médicos y cirujanos p. 213- 214. En opinión de Monseñor Sanabria el padre Calvo escribió 
Según el historiador Rafael Obregón, en las filas filibusteras hubo una cifra de doscientas a doscientos cincuenta muertes. ${ }^{64}$ Walker se retiró en la madrugada del día siguiente hacia Granada, lo que resulta sorprendente ya que él tenía la ventaja de conocer el terreno, así como la posición en que se encontraban las tropas costarricenses, los recursos de la ciudad y poseía la experiencia de haber luchado en ella.

El día 12 de abril el presidente Mora dio orden de enterrar los muertos, entre ellos varios oficiales que fueron enterrados en la iglesia de San Francisco. También se procedió a organizar una especie de hospital, para la atención de los heridos. Los médicos a cargo de esta tarea fueron: Carl Hoffman, un súbdito alemán quien prestó servicios en calidad de voluntario y se desempeñó como médico cirujano mayor del Ejército, Francisco Bastos y Andrés Sáenz. Estos contaron con el apoyo del asistente Carlos Moya. Francisca Carrasco, recientemente visibilizada por la historiografía, se encontraba, entre las mujeres que ayudaron a consolar a los moribundos y atender a los heridos, también se ocupaba como cocinera y en más de una ocasión realizó tareas militares. ${ }^{65}$

Días más tarde, llegaron los doctores Cruz Alvarado, quien se encontraba atendiendo los heridos de Santa Rosa en Liberia y Fermín Meza. La atención de los heridos requirió el traslado de nuevos cargamentos de medicinas desde San José, que fueron enviados el 28 de abril. La urgente necesidad de servicios médicos provocó que los doctores Alejandro Frantzius, otro voluntario alemán quien había asistido a las tropas en Sarapiquí, y Bruno Carranza, se pusieran en camino de Rivas. En Liberia, el doctor Santiago Hogan, levantó un hospital de emergencia para atender a los heridos procedentes de Nicaragua. Al doctor Marquis L. Hine se le encomendó la atención de los heridos que llegasen al puerto de Puntarenas, en los días posteriores. ${ }^{66}$ Estas referencias nos revelan que el cuido de los heridos y los enfermos fue designado, por las autoridades políticas, a los pocos médicos que existían en Costa Rica, muchos de los cuales eran extranjeros y se habían ofrecido de voluntarios.

Mora dio prioridad a la atención de los heridos y al fortalecimiento del ejército. Su

su libro al regreso de Nicaragua después de recoger las noticias que pudo. Eladio Prado, apunta que tanto el Libro primero como el segundo, fueron escritos por Calvo en 1857. Sanabria, Víctor Manuel "Una relación de la Batalla de Rivas” El Mensajero del Clero, Número 5, mayo de 1930, 153.

$64 \quad$ Obregón, Rafael Costa Rica y la guerra, 133.

65 Hilje Quirós, Luko Karl Hoffman: naturalista, médico y héroe nacional. 1a. edición. (Santo Domingo de Heredia Costa Rica: Instituto Nacional de Biodiversidad INBIO, 2006) 57

66 ANCR Guerra y Marina, 8848,1856, fs.1-10. 
propósito era perseguir a Walker hasta Granada, pero una vez que hubiesen llegado refuerzos, especialmente por vía marítima desde Puntarenas, y se enviaran los heridos a Liberia y Puntarenas. Con ese objetivo el comandante de las fuerzas militares en Puntarenas José María Cañas contrató varias embarcaciones. La decisión de retirarse de Rivas sin perseguir al enemigo, quien se hallaba fuertemente debilitado, fue cuestionada por algunos de sus contemporáneos, ya que consideraban que Walker era un blanco fácil, al que debía liquidarse militarmente para finiquitar la guerra. ${ }^{67}$

Los relatos sobre las terribles imágenes de esos días, entregados por algunos de los participantes en la contienda ${ }^{68}$ son realmente impresionantes, ya que en ese entonces, se desconocían las normas de asepsia, los anestésicos, los antibióticos, por lo que los dolores eran desgarradores y las infecciones se propagaban rápidamente. El relato del Dr. Sáenz, uno de los pocos médicos que ayudaron al Dr. Hoffman en la asistencia a los heridos, yendo de casa en casa "echado de barriga” para cuidarse de las balas, evidencia parte de esta situación.

"Si un hospital de guerra es siempre una cosa terrible, en aquella época, en que aún no se conocían entre nosotros, los anestésicos, era un espectáculo del cual no se puede tener idea cabal sin haberlo visto. ¡Cuánta miseria y cuánto sufrimiento! Para colmo de males, la epidemia del cólera vino pronto a triplicar nuestra tarea ya pesada”. ${ }^{69}$

\section{El cólera aparece entre la tropa y se expande con rapidez}

El historiador Rafael Obregón afirma que el primer caso de cólera en las filas del ejército costarricense fue detectado por los médicos del ejército el 20 de abril. ${ }^{70}$ Existe otra versión de que este hecho ocurrió el 16 de abril. ${ }^{71}$ En un parte del ejército, publicado en la edición del 30 de abril del Boletín Oficial, en San José, se señalaba que el 21 de abril la situación de la "salubridad" era buena y que el número de enfermos era mínimo "aunque personas asustadizas se complacen

67 Obregón, Rafael Costa Rica y la guerra pp.119-141.

68 Hilje Quirós, Luko Karl Hoffman: naturalista, médico y héroe nacional, 57-61

Zeledón Cartín, Elías (compilación) Crónicas de la guerra nacional 1856-1857. 1ª . Edición (San José, Editorial Costa Rica, 2006). Excelente compilación de memorias que incluye la de Víctor Guardia, Andrés Sáenz, Jacinto García, José Maria Bonilla, Ezequiel Herrera, Máximo Blanco y otros textos alusivos a la gesta escritos por contemporáneos, periodistas y otros.

$69 \quad$ Sáenz Andrés, Revista de los Archivos Nacionales (Costa Rica) 5 y 6 (marzo-abril 1939): 329-330. En: Zeledón Cartín, Elías (compilación) Crónicas de la guerra nacional 1856-1857, 89.

70 Obregón, Rafael. Costa Rica y la guerra, p.145.Obregón refiere a Jacinto García, quien señala que el primer afectado del cólera fue el soldado José María Quirós procedente del barrio de la Soledad de San José.

71 Esta es la versión de Raúl Arias, apoyándose en el Libro de Defunciones del padre Calvo. Médicos y cirujanos, 224 
en ver en cada enfermedad un síntoma epidémico, podemos asegurar con toda verdad, que solo enfermedades muy comunes aquejaban a 15 o 20 soldados, no obstante el inconsiderado abuso que hacen devorando las esquisitas y abundantes frutas de Nicaragua". ${ }^{72}$

Lo cierto es que en días posteriores a la batalla del 11 de abril aparecieron nuevos casos y la enfermedad tendió a multiplicarse y a producir la muerte de soldados y oficiales. El bacilo requiere un corto período de incubación, por lo que en menos de 12 horas, después de una fuerte diarrea que produce la pérdida de líquidos y sales minerales, que causa postración y ansiedad, se llega, generalmente, a la muerte. Hoffman, pese a tener experiencia en el manejo del cólera, no se encontraba en condiciones de asesorar de la mejor manera al presidente Mora, ya que en esa época no se conocía el origen de la enfermedad, ni las vías de transmisión, aunque ya circulaba la idea de la importancia del agua. En consecuencia, el presidente Mora se basó en la teoría de los vapores miasmáticos, tal y como lo revela el texto a continuación, publicado en el Boletín Oficial, que suponía que las emanaciones de cuerpos enfermos, la materia en descomposición, las aguas estancadas y "un clima insalubre”, eran el origen de la enfermedad. Asimismo, en correspondencia con esta hipótesis, tomó la decisión de que había que retirarse de Rivas y desplazarse hacia territorio costarricense. ${ }^{73}$

"A nuestra salida al amanecer del día 24 pasado creíamos que algunos rumores que circulaban en Rivas, eran efecto tan solo del apocado espíritu de personas asustadizas que creen ver en cada enfermo un síntoma epidémico....Pero nos engañamos: era el cólera que amagaba y empezaba su desarrollo fatal... ¿Cómo combatir a ese enemigo en un clima abrasador, donde la maléfica estación de las lluvias comienza (...) una epidemia es un enemigo incombatible que, si no arranca los laureles adquiridos, destruye a los héroes que han conquistado y sobrevivido a la victoria."74

Esa retirada era muy complicada puesto que más de trescientos hombres se encontraban heridos, otros más se hallaban en estado lamentable producto del cólera, también había que trasladar las municiones y armamentos hasta San Juan del Sur, puerto que se encontraba bajo control de los costarricenses, muy cerca de la frontera. Para ese efecto eran fundamentales

72 Boletín Oficial, 30 de abril de 1856, p.424. Según Rafael Obregón el autor de este texto era de Emilio Segura, y tenía el propósito de tranquilizar a las personas en la capital, ya que no se tenían noticias de los heridos y muertos en la batalla. Del cólera no se hace mención, pese a que ya se habían presentado varios casos. Obregón, Rafael. Costa Rica y la guerra, 152. Se respeta la ortografía original.

73 Hilje Quirós, Luko Karl Hoffman: naturalista, médico y héroe nacional, 58-59.

74 Boletín Oficial, 3 de mayo de 1856, p.429. 
los barcos contratados en Puntarenas: “Telemby”, Dominga Morales y “Tres Amigos”, por el comandante en ese lugar Juan Manuel de Cañas, pero estos tardaron en llegar. ${ }^{75}$ El bergantín Telemby, fue el primero en arribar a San Juan del Sur. En el regreso a Puntarenas, su capitán recibió órdenes del presidente Mora, para que se detuviera en playas del Coco, dejara allí a los heridos, para posteriormente trasladarlos en carreta a Liberia y recogiera parte del equipo militar que se encontraba en esa ciudad.

En los barcos “Telemby” y “Tres Amigos”, los únicos en llegar a San Juan del Sur porque el Dominga Morales sufrió una avería, el cólera hizo su aparición provocando la muerte de varios hombres, por lo que sus cadáveres fueron lanzados al mar, incluido el del capitán del Telemby, Juan Bautista Iriarte. Ambos barcos se dirigieron a Puntarenas donde desembarcaron las armas, posteriormente se enrumbaron hacia el puerto de Caldera para desembarcar a las tropas que venían a bordo y prestarles servicio de alimentación y atención médica. ${ }^{76}$

El resto del ejército, junto a los heridos que comenzaban a restablecerse, inició el regreso a Costa Rica por vía terrestre. Algunos de los enfermos del cólera se encontraban en tal gravedad que fueron dejados en Rivas, ya que era imposible transportarlos. Empero, el general Cañas, a cargo de la retirada, le envió una carta a Walker, quien se dirigía a Rivas con el propósito de atacar al ejército costarricense antes de que se alejara, pidiéndole respetar la vida los enfermos y proponiéndole un futuro canje de prisioneros. Cañas duró dos días en llegar a la frontera, el 30 de abril acampó en Sapoá, donde le fue imposible contener a la tropa y a algunos oficiales, que se encontraban aterrorizados y corrían en desbandada hacia Liberia. De tal manera que todos los esfuerzos realizados por Mora y su equipo para establecer depósitos de víveres, con el fin de que los soldados se abastecieran en diferentes puntos del camino y caminaran en pequeños grupos resultaron infructuosos. Muchos soldados murieron de hambre o afectados por la epidemia, durante la retirada. ${ }^{77}$

El general Cañas junto a una compañía de zapadores, a quienes entre promesas y amenazas, mantenía para poder enterrar a los muertos y atender a los heridos, se mantuvo en la retaguardia. El 3 de mayo ingresó el último grupo de soldados a Liberia. Al día siguiente murieron en esa ciudad el subsecretario de Relaciones Exteriores, el francés Adolphe Marie de cólera y el coronel

75 ANCR, Guerra y Marina, 13477, 1856, fs.3-10

76 Obregón, Rafael. Costa Rica y la guerra, 148-149

77 Ibid., 150 
Alejandro von Bülow de disentería. ${ }^{78}$

El presidente Mora, quien se encontraba en Liberia, al igual que el resto de los hombres, estaba convencido de que el cólera, una vez pasada la frontera se convertiría en colerín: "es una felicidad que el horrible contagio no pueda combinarse con la atmósfera de este departamento". ${ }^{79}$ Los informes del general Cañas lo obligaron a reconocer la gravedad de la situación. El 4 de mayo, el presidente Mora, a instancias de Cañas, abandonó esa ciudad para enrumbarse a Bagaces y luego a Puntarenas. Cañas permaneció en Liberia a cargo del cuido de la frontera y de un cordón sanitario. En su retirada e inocente de la forma en que se producía el contagio, Mora guardaba la esperanza de que el país se librara del cólera, ya que los muertos de cólera en Liberia habían llegado enfermos a esa villa. ${ }^{80}$

\section{Las causas de la epidemia}

La información histórica disponible revela que la epidemia azotó con mayor intensidad al ejército costarricense que a las tropas filibusteras. El doctor Leonardo Mata ha indicado, con la poca evidencia disponible, que en ese hecho influyeron varios factores, entre ellos la larga marcha realizada por los soldados, principalmente a pie desde Cartago y otros lugares de Costa Rica hasta la ciudad de Rivas. En esta jornada, la tropa debió salvar los obstáculos planteados por el relieve, la hidrografía y el clima, lo que la condujo a la pérdida de importantes reservas nutricionales y energéticas. La exposición, por parte de los soldados, a un clima caliente y deshidratante, diferente al del Valle Central, produjo una mayor deshidratación entre los provenientes de esa región. El relato de un sencillo soldado ilustra la situación:

"Nojotros íbamos a pie y en las bestias iba el parque y más bastimento. Las "clases" también iban a caballo. No quiera un acordarme desas caminadas tan grandes, por esos llanos de La Garita, después el Alto del Aguacate, el Desmonte, San Mateo, El Higuito, Surubres, Los Nances, Esparza....hasta que llegamos a los llanos del Departamento, (Guanacaste) más muertos que vivos porque las jornadas eran muy groseras...con esos soles y uno que seogaba porque en esos llanos noay agua y la que llevaban las yeguas de carga nos alcanzaba solo pun traguito a caduno.” 81

$78 \quad$ Ibíd., 151.

79 Comunicación del 1 de mayo. ANCR Guerra y Marina 8827, fs. 8-9. En: Obregón, Rafael. Costa Rica y la guerra, 150

$80 \quad$ ANCR Guerra y Marina, 8827, fs 13 y 14. "Campaña contra el cólera morbus y auxilio a las víctimas de guerra “(Colección de documentos) Revista de los Archivos Nacionales (Costa Rica) 1-6 (enero-junio1962).

81 La Nación, 11 de abril de 1856, 21. En: La vida cotidiana de nuestros abuelos (1801-1910) Crónicas 
Entre los factores determinantes de la propagación de la enfermedad se encuentran los siguientes. La permanencia de los soldados en unas pocas casas sitiadas, dentro de espacios reducidos, por largas horas, durante la batalla de Rivas hasta la quema del Mesón de Guerra. El consumo de agua y alimentos contaminados, la carencia de apoyo logístico entre los residentes de la ciudad para facilitarse una buena alimentación y la ausencia de una inmunidad previa, debido a que era la primera vez que se ponían en contacto con la enfermedad, a diferencia de la población nicaragüense y filibustera. ${ }^{82}$

Las descripciones de la batalla de Rivas y del sitio de la ciudad hacen suponer a Mata que el contagio se produjo, en primera instancia, al consumirse agua de pozos expuestos a la contaminación con heces depositadas en el suelo, ya que la mayoría de la población defecaba en los solares a campo abierto, no se construían pozos negros y cuando los había, rara vez se tapaban. Sobre la contaminación de los pozos de agua para consumo, se supone que, aunque las lluvias eran raras en ese mes del año, estas deben haber ocurrido, provocando así que las heces depositadas en el suelo se lavaran hacia los pozos. También, Mata señala que es factible que se haya dado la transmisión persona a persona y por el consumo de alimentos contaminados, dada la pésima condición higiénica de la tropa.

Algunos autores han expresado que los cuerpos sin vida de 200 costarricenses y 50 filibusteros fueron arrojados en las letrinas y pozos de Rivas, mientras centenares yacían en los improvisados hospitales con heridas ulceradas y mal asistidos. ${ }^{83}$ Esta afirmación es refutada por Manuel Carazo Peralta, traductor del libro de Roche, quien señala que los muertos del ejército costarricense fueron enterrados el 12 de abril y que fueron los filibusteros quienes arrojaron a los suyos a los pozos del Mesón. Lo mismo señala Víctor Guardia, un testigo presencial de los hechos, "era necesario que ésta (la peste del cólera) apareciese en Rivas, donde la sangre de las calles entraba en putrefacción. Los filibusteros arrojaban sus muertos a los pozos que surtían de agua a la población, de manera que cada uno de ellos era un foco de corrupción que debía dar sus resultados”. Historiadores concuerdan en que pudo haber sido una actitud premeditada por parte de William Walker, quien probablemente se encontraba en conocimiento de la importancia de las aguas en la propagación de las enfermedades. En consecuencia, no podía dejar pasar la

Compilación de Elías Zeledón, 158. Se respeta el habla popular.

82 Mata, Leonardo Cólera. Historia, prevención y control pp.57-58.

83 Roche, James Jeffrey The story of the filibusters. (New York, 1891) Citado por Mata, Leonardo, Cólera. Historia, prevención y control, p.58. 
oportunidad, para diezmar al enemigo por la vía más fácil.

El doctor Mata ha llegado a la conclusión, basándose en los relatos de varios participantes en la contienda, de que es muy probable que la epidemia del cólera fuera precedida por la disentería, o que se dieron en forma simultánea, debido a que los textos refieren a personas que presentaron diarrea con fiebre, retortijones y dolores abdominales, síntomas típicos de esa enfermedad infecto contagiosa, pero no del cólera. Además los médicos emplearon el láudano, tintura de opio, en forma generosa para apaciguar los dolores. Un tratamiento utilizado para atenuar las molestias causadas por la disentería en aquella época. En suma, las instrucciones médicas y los tratamientos, debido al poco desarrollo de la medicina, no siempre eran los más apropiados, un efecto beneficioso se producía, muchas veces, en forma intuitiva o indirecta.

Las instrucciones del Dr. Hoffman, dirigidas a la población en el desarrollo de la epidemia, eran las mismas que se solían dar en Europa en ese entonces. Indicaba que había que reprimir el sentimiento de miedo y pusilanimidad, evitar las emociones, los pesares, los arrebatos coléricos y dedicarse a la sociabilidad. No había que renunciar a las costumbres adoptadas con respecto a ejercicio o dieta. Se recomendaba una dieta “sana”, pero se prohibían las frutas y los dulces, lo que en realidad no tenía ningún efecto. Entre los médicos era común asociar el cólera a una enfermedad del aparato digestivo. ${ }^{84}$

La casa y la ropa limpia debían permanecer limpias y no mojarse para evitar los resfríos. En caso de que se presentara la enfermedad, debía recurrirse a un facultativo, pero mientras se conseguía este, se aconsejaba suministrar al enfermo, cada media hora, una cucharada de aguardiente alcanforado hasta que se desvaneciera el hielo del cutis y se produjeran sudores calientes. ${ }^{85}$ En ese entonces, los licores eran muy recomendados porque se consideraba que el cólera y en general las enfermedades, se presentaban cuando el organismo se enfriaba. El alcanfor se administraba para alejar los malos olores. ${ }^{86}$ Hoy sabemos que esa instrucción resultaba positiva porque reconfortaba, tranquilizaba y calentaba a los enfermos, pero que lo más importante era hidratar adecuadamente a las personas.

\section{Las respuestas institucionales y sociales ante la epidemia}

$84 \quad$ Carbonetti, Adrián. Rodríguez, María Laura “Las epidemias de cólera en Córdoba a través del periodismo: la oferta de productos preservativos y curativos durante la epidemia de 1867-1869" História, Ciencias. Saúde-Manguinhos (Río de Janeiro) 14, n.2 (abril-junio 2007) 411.

$85 \quad$ Boletín Oficial, 14 de mayo de 1856, 440.

86 Carbonetti, Adrián. Rodríguez, María Laura “Las epidemias de cólera en Córdoba”, 411. 
El retorno de los primeros heridos y enfermos a San José se produjo el 5 de mayo. ${ }^{87}$ En esos días la enfermedad se diseminó por el territorio debido a la costumbre de los pobladores de defecar en campo abierto. Esta situación provocó la contaminación de las aguas ya que las heces eran esparcidas por las lluvias hasta los pozos, ríos y quebradas. También contribuyó la acción de las personas afectadas por la diarrea, quienes buscaron la cercanía de las fuentes de agua para lavarse, exponiendo así al resto de la población que se abastecía de esas aguas. Asimismo, las personas se encontraban imposibilitadas de bañarse diariamente y lavarse las manos antes de las comidas, debido a la ausencia de infraestructura sanitaria y el desconocimiento de los hábitos higiénicos. Por otra parte, la dieta era mala ${ }^{88}$, poco digerible, abundante en alimentos feculosos, manteca de cerdo y a menudo insuficientemente cocida y la desnutrición era prevaleciente en todas las edades. ${ }^{89} \quad$ El Hospital San Juan de Dios no se encontraba en condiciones óptimas para recibir a enfermos y heridos y al igual que los hospitales de la época era concebido para albergar a quienes no tenían familiares que les cuidasen. Un grupo de señoras de la elite, presidido por Inés Aguilar, la esposa del presidente Mora, recolectó ropa de cama y medicamentos para habilitar cien camas. Entre los pacientes se encontraban varios filibusteros, la mayoría desertores, quienes fueron tratados con consideración y posteriormente se facilitó el regreso a su país. ${ }^{90}$

En circular a los gobernadores, con fecha 7 de mayo, el ministro de Gobernación ordenó dar puntual cumplimiento a las medidas establecidas en 1837 en todos los pueblos del territorio. ${ }^{91}$ Estas instrucciones no tuvieron carácter preventivo, sino que fueron ordenadas y parcialmente aplicadas, simultáneamente al desarrollo de la epidemia. ${ }^{92}$

$87 \quad$ Boletín Oficial, 7 de mayo de 1856, 431.

$88 \quad$ En esta ponencia no hemos introducido el tema de la alimentación, sin embargo este es muy importante para estudiar el impacto de las epidemias. Generalmente, las epidemias se encuentran vinculadas a crisis previas de subsistencias. En el caso costarricense la historiadora Yamileth González ha demostrado que hasta 1840 los períodos de escasez de alimentos se suceden unos a otros, aunque después de esta fecha disminuyen y se controlan fácilmente. González, Yamileth Continuidad y cambio en la historia agraria de Costa Rica (San José: Costa Rica: Editorial Costa Rica, 1985) 237.

El tema de la dieta, especialmente de los sectores populares, y del abastecimiento de alimentos de las poblaciones: mercados y redes de distribución, es necesario desarrollarlo para conocer las condiciones de salud de la población y su capacidad de respuesta al embate de la epidemia. Serrallonga, Joan "Epidemias e historia social”11-14.

$89 \quad$ Mata Leonardo. Cólera. Historia, prevención y control, 71, 74,75.

90 ANCR Serie Beneficencia 100, 1856-1857, 9 folios. En: Revista del Archivo Nacional.(Costa Rica) 1-12 (enero-diciembre 1966): 175-193.

$91 \quad$ ANCR. Gobernación 100, 1856, folio 65. “Campaña contra el cólera morbus y auxilio a las víctimas de guerra “(Colección de documentos) Revista de los Archivos Nacionales

$92 \quad$ Las medidas son las que se comentan en las páginas 13 y 14 de esta ponencia. 
Los médicos de pueblo en cada provincia y comarca, una figura decretada en 1847, prácticamente no existían, con la excepción de la capital. El gobierno se vio obligado a contratar médicos, empíricos y a las personas que los gobernadores consideraron idóneas, después de recibir instrucciones de los médicos, investidos con las funciones de médico de pueblo, para que prestaran asistencia y distribuyeran medicinas. Un médico filibustero capturado por las tropas costarricenses prestó sus servicios durante la epidemia en la villa de Liberia. El presidente Mora le agradeció los servicios prestados y ordenó se le pusiera en libertad para que se trasladara al punto que deseara "con tal de no tomar el camino de tierra para Nicaragua". ${ }^{93}$ Esto indica que las autoridades estuvieron dispuestas a recibir ayuda, para atender y calmar a la población, de personas “no legitimadas” para el ejercicio de la profesión médica: los curanderos y un médico filibustero en condición de preso político.

El gobierno pagó las facturas, presentadas por los médicos y curanderos a las municipalidades y gobernaciones, por servicios prestados en la atención de los enfermos de cólera de los diferentes pueblos, villas y ciudades. También canceló las facturas presentadas por compra y administración de medicamentos a los enfermos pobres. Es interesante observar que los tratamientos de unos y otros eran muy semejantes y que gran parte de los medicamentos contenían opio como ingrediente. ${ }^{94} \mathrm{El}$ opio tranquilizaba y calmaba a los enfermos, los hacía dormir y si los enfermos lograban hidratarse, se encontraban en mejores condiciones de sobrevivir. Todo lo cual nos conduce a afirmar que la distancia entre médicos y curanderos era muy tenue y que todavía la medicina se encontraba en una etapa embrionaria.

Se giraron instrucciones para que en cada cantón se construyera un carro o carreta, con el presupuesto de los fondos de policía, para trasladar al cementerio a los muertos del cólera, los cuales debían ser enterrados rápidamente, muchos de ellos en fosas comunes. La falta de personal condujo a que se autorizara el uso de presidiarios para esas labores. ${ }^{95}$ Los relatos de la época dan cuenta de que los presos cumplían con sus tareas bajo los efectos del licor, con el fin de calmar sus miedos y temores. Los presos que no se fugaron y cumplieron con sus deberes fueron retribuidos con su libertad. ${ }^{96}$

Se calcula que falleció entre un 8 y un10 por ciento de la población, la mayoría procedente

$93 \quad$ ANCR. Gobernación 100, 1856, folio 65. “Campaña contra el cólera morbus y auxilio a las víctimas de guerra “(Colección de documentos) Revista de los Archivos Nacionales : f.85

$94 \quad$ ANCR Gobernación

$95 \quad$ Ibíd., fs 73 y 74.

96 Ibíd.., f. 107 
de los sectores populares, y ubicados en el Valle Central, aunque el cólera se dispersó por todo el territorio. Los adultos, y especialmente las mujeres fueron el sector de la población más afectado. Es decir, que a diferencia de lo que ocurría en los tiempos normales, la mayoría de las muertes no eran de niños, sino de mujeres adultas. Esto tuvo un fuerte impacto sobre la tasa de fecundidad y por ende, sobre el crecimiento de la población. La crónica escasez de mano de obra se agudizó y contribuyó a elevar los jornales. ${ }^{97}$

La epidemia golpeó de preferencia a los sectores populares, ya que estaban peor alimentados, carecían de reservas de alimentos, desconocían los hábitos higiénicos, no siempre tenían quien los atendiese en caso de enfermar, ni con qué tratarse y no siempre pudieron aislarse a sus fincas para sortear la enfermedad. Entre los afectados estuvo el mismo presidente Mora, quien logró recuperarse en su finca de Ojo de Agua, al igual que el militar Víctor Guardia, quien cuenta en sus memorias de la guerra, que cuando regresaba a San José, tuvo que desviarse del camino, a una de sus propiedades situadas en el Guanacaste para reponer su salud. También, asombra conocer que el general Cañas regresó sano a San José después de permanecer en cercano contacto con la enfermedad. Sin embargo, hubo muertos ilustres como el vicepresidente en ejercicio, Francisco María Oreamuno y el ex jefe de Estado José María Alfaro y su esposa, estos últimos residentes en la ciudad de Alajuela. ${ }^{98}$

Una de las respuestas institucionales más importantes, debido a los efectos posteriores, fue la creación del Protomedicato de la República el 28 de octubre de 1857, “con el fin de proteger la salud pública y controlar el ejercicio de la medicina”. ${ }^{99}$ En opinión del historiador Ronny Viales, esta institución marcó "un antes y un después en la historia del campo de las artes de curar y de la profesión médica”. ${ }^{100}$ El Protomedicato, impulsado principalmente por las autoridades políticas, quienes se vieron desbordadas durante la epidemia del cólera, y la Sociedad Médica, fueron instalados el 1 de abril de 1858. La ley estableció amplias funciones para ambas instancias, que 97 Rodríguez, Eugenia "Estructura crediticia, coyuntura económica y transición al capitalismo agrario en el Valle Central de Costa Rica, 1850-1860” (Tesis de maestría en Historia, Sistema de Estudios de Postgrado, Universidad de Costa Rica, 1988).

98 La duración y el impacto demográfico de la epidemia en el valle Central, se encuentran detalladamente explicados en: Tjarks, German et al “La epidemia del cólera de 1856” Pérez Brignoli, Héctor “Reconstrucción de las estadísticas parroquiales de Costa Rica 1750-1900” Revista de Historia (Costa Rica) n.17, 1988, 269

99 Decreto No. 36, 29 de octubre de 1857. Oficial Colección de Leyes Decreto y Ordenes expedidas por los Supremos Poderes Legislativo y Ejecutivo de Costa Rica (San José: Imprenta de la Paz) 149-152.

100 Viales, Hurtado Ronny “La profesión farmacéutica en la Costa Rica liberal. Entre el apoyo estatal, el mercado y la clausura corporativista, 1854- 1907” Anuario IIEHS-Instituto de Estudios Histórico-Sociales “Prof. Juan Carlos Grosso” (Argentina) 21, 2006:427. 
en reglamentos posteriores fueron mejor delimitadas. Compartimos la opinión de Viales de que su creación significó un serio intento de esbozar una política pública en el ámbito de la salud, más allá del control de empíricos e "irregulares”, puesto que al respecto existían disposiciones desde la época colonial, las que por supuesto no se cumplían, debido a la imposibilidad objetiva de llevarlas a la práctica. Esta instancia, también constituyó el antecedente de la Medicatura Forense, sumamente necesaria en un contexto de profundos cambios sociales e institucionales. La Sociedad Médica, como bien apunta Viales, representa un indicador del nivel que comenzaba a alcanzar la práctica corporativa en el seno del gremio médico. ${ }^{101}$

Estos señalamientos de Viales, nos conducen por una línea investigativa que el historiador Ricardo González Leandri ha introducido en América latina, por medio del estudio de la formación del campo médico en la ciudad de Buenos Aires en el período 1852-1900. ${ }^{102}$ González Leandri demuestra los vínculos entre la formación de un campo médico y la construcción y consolidación del Estado, lo que conduce a evidenciar que los médicos lograron una mayor autonomía como corporación, a nivel de las relaciones de poder, conforme el Estado aumentó su ingerencia en asuntos de salud. Asimismo, observa que los médicos utilizaron la lucha contra el curanderismo, en un momento en que sus fronteras no estaban muy delimitadas, debido al poco desarrollo de la medicina "para ir definiendo, a partir de sus bordes, su propia imagen profesional". ${ }^{103}$

El reglamento que regulaba y definía las actividades y jurisdicciones del Protomedicato, promulgado el 15 de junio de 1858, otorgó a los médicos el “monopolio cognitivo” que aspiraban a detentar, mediante la fiscalización de exámenes a los aspirantes a ejercer la profesión, el control del ejercicio de la profesión y el derecho de perseguir a los curanderos e "irregulares". Esto fue fundamental en el proceso de su consolidación como campo profesional, ya que les otorgó el control del monopolio de la curación y una posición envidiable para disciplinar, subordinar y excluir a los otros sectores vinculados con el ámbito de la salud: matronas, enfermeras, $101 \quad$ Ibíd.: 428

102 Ricardo González Leandri “La profesión médica en Buenos Aires: 1852-1870” En: Lobato Z. Mirta Política, médicos y enfermedades. Lecturas de historia de la salud en la Argentina (Buenos Aires, 1996) 2153. Curar, persuadir, gobernar. La construcción histórica de la profesión médica en Buenos Aires, 1852-1886 (Madrid: Consejo Superior de Investigaciones Científicas de España- Centro de Estudios Históricos, 1999)1- 259. "El Consejo Nacional de Higiene y la consolidación de una elite profesional al servicio del Estado. Argentina, 1880-1900”Anuario de estudios americanos (Sevilla, España) n.61,2, 2004,571-593. “Campos e imaginarios profesionales en América Latina. Renovación y estudios de caso”Anuario Instituto de Estudios Histórico- Sociales "Prof. Juan Carlos Grosso” (Argentina)n. 21,2006, 331-344. 
farmacéuticos, odontólogos y todo tipo de practicantes de curaciones. ${ }^{104}$ En consecuencia, una vez concluida la epidemia, el gobierno impartió órdenes para poner fin a la "alianza" con los empíricos, por lo que se prohibió que siguieran practicando la medicina, pese a que muchos de ellos habían prestado sus servicios, por cuenta del Estado, durante la epidemia del cólera y eran muy estimados por la población. ${ }^{105}$

La creación del Protomedicato bajo predominio médico, como bien lo estudia Viales, dejó a los farmacéuticos en un situación ambigua, ya que las disposiciones emitidas por la entidad, se orientaban de preferencia, a controlar la actividad de los farmacéuticos, pero nada se disponía contra los médicos que violaban las normas establecidas. El conflicto radicaba en que varios médicos, poseían también su propia farmacia, y no aceptaban que ese campo era de incumbencia de los farmacéuticos. El reglamento del Protomedicato fue reformado en 1859, por iniciativa de los farmacéuticos, pero los médicos insistieron en que mientras no hubiera por los menos cuatro farmacéuticos en la capital y dos en cada provincia, los médicos podían conservar sus boticas. ${ }^{106}$

La eliminación del Protomedicato Médico y su sustitución por la Facultad de Medicina, Cirugía y Farmacia en 1895, significó un nuevo avance en la conformación de un campo médico y en la subordinación de las otras profesiones y actividades vinculadas a la prevención y cura de enfermedades. El Reglamento de la Facultad le otorgó superiores atribuciones con respecto a las poseídas por el Protomedicato, entre ellas la que permitía a la Junta de Gobierno, integrada mayoritariamente por médicos, otorgar permisos a las personas que "merecieran su confianza" para vender drogas de consumo masivo en los pueblos, siempre que no existiera botica regentada por médico o farmacéutico. ${ }^{107}$ Finalmente, una vez que los farmacéuticos se percibieron numérica y académicamente fuertes, desarrollaron un movimiento segregacionista dentro de la Facultad, para transformarse en Colegio de Farmacéuticos en 1902. Esto significó impulsar un conjunto de acciones, peticiones y mecanismos formales e informales, en la esfera política, para obtener el control de su propio espacio organizativo y académico. ${ }^{108}$

El cólera, por su llegada intempestiva y sus efectos desastrosos sobre el modo de vida,

104 Este proceso fue estudiado por González Leandro para el caso argentino. Viales estudia las estrategias de subordinación de los médicos con respecto a los farmacéuticos en Costa Rica.

105 Decreto No.36, 29 de octubre de 1857. Colección de leyes y decretos, f. 126.

106 Viales H. Ronny “La profesión farmacéutica”, 427-428.

107 Ibid., 430-431.

108 Ibíd., 432-433 
mayoritariamente campesino, provocó todo tipo de temores, angustias y miedos en la población. Las condiciones materiales de vida, propias de esa sociedad, unidas al sistema de creencias religiosas basadas en el catolicismo y al limitado desarrollo educativo y científico de la época se conjugaron para impedir la puesta en práctica de medidas preventivas o curativas acertadas. El desconocimiento del origen y la transmisión del cólera, sumado a las concepciones religiosas católicas sobre el origen de las enfermedades, trastornaron por completo a gran parte de la población.

La población del Valle Central bajo control ideológico de la Iglesia Católica, estaba acostumbrada a la prédica de la jerarquía religiosa y de los curas en torno al pecado. El pecado de los feligreses era la causa de las miserias, dolores y enfermedades de los pobladores. Como lo demuestra Esteban Rodríguez ${ }^{109}$ en su trabajo sobre la vivencia religiosa de las catástrofes en el occidente del Valle Central entre fines del siglo XVIII y 1852, un minuto de "placer, lujuria, avaricia o soberbia” podía costar muy caro a los pobladores, no solo por los efectos inmediatos, sino por la posibilidad de fallecer abruptamente sin los auxilios sacramentales, necesarios para asegurar el adecuado tránsito a la otra vida. ${ }^{110}$

El relato de una mujer de la época lo atestigua: “Aquello fue como un castigo de Dios... Hubo gente que enfermó de miedo, a mi mamá le ocurrió; se vistió lo mejor que pudo y se acostó a aguardar la muerte..."111

Frente al miedo aterrador a lo desconocido, el pueblo se refugió en la religiosidad, algo que constituye una constante en todas las grandes epidemias y catástrofes. Buscó afanosamente el mejor intercesor con Dios para conquistar su piedad y su perdón. En consecuencia, en las calles se sucedieron las procesiones, con todo tipo de santos, para conjurar el mal. Sin embargo, la rogativa que más impactó en la ciudad de San José, fue la efectuada en la Iglesia de la Catedral el 14 de junio de 1856, dedicada al Dulce Nombre de Jesús. ¿Qué ocurrió en esa fecha para percibir que ese culto era el indicado? Ese es un asunto a investigar, probablemente un estudio detallado de la mortalidad nos ayude al respecto. El obispo Anselmo Llorente y Lafuente avaló este nuevo culto, cuya devoción promovió Adolfo Calderón, su mayordomo oficial. ${ }^{112}$ Un elemento a tener

109 Rodríguez D., Esteban “Catástrofes y mentalidades”, 156-157.

110 Ibíd., 153. Al respecto son muy sugerentes las reflexiones de Ariés, Philippe El hombre ante la muerte Barcelona: Paidós, 1987.

111 Elizondo, Víctor Manuel En: Álbum de Granados. Tomo 5, 124. En: Zeledón, Elías (comp.) La vida cotidiana de nuestros abuelos (1801-1910) Crónicas ,172.

112 Archivo de la Curia. Fondos Antiguos. Documentación suelta 1853-1856. Caja No.5 Sobre las 
en cuenta, es el papel de la Iglesia católica en la Campaña Nacional y de la mayoría de los sacerdotes en el auxilio a los heridos y enfermos durante la guerra y en el desarrollo de la epidemia, lo que promovió una mayor religiosidad entre los costarricenses.

\section{Conclusiones}

Las condiciones del contexto que se han señalado a lo largo del texto, especialmente lo relativo a las condiciones de vida de la población, el tipo de vivienda, las formas de abastecimiento de agua, la alimentación, la infraestructura sanitaria y las prácticas higiénicas permiten imaginar que la sociedad costarricense de la época no estaba preparada para enfrentar la epidemia del cólera en 1856. Mucho menos en las condiciones de desinformación e improvisación en que se desarrolló la epidemia, debido a que el gobierno se negaba a aceptar la presencia de la enfermedad por razones políticas e influido por las concepciones imperantes sobre el origen de las enfermedades.

En ese momento, apenas se iniciaba la construcción de dos hospitales, los cuales dependían en gran medida de legados y donaciones, concebidos como espacios para albergar la "humanidad doliente", a los enfermos pobres, carentes de familiares que se hicieran cargo de ellos. La figura del médico de pueblo daba sus primeros pasos, aunque la carencia de estos, aunada a la falta de financiamiento, hace presumir que su efecto era extremadamente limitado y se reducía a la capital. Por otra parte, el escaso desarrollo de la medicina, propiciaba que la población se encontrara en condiciones de vulnerabilidad frente a las temidas epidemias.

La catástrofe demográfica tuvo un fuerte impacto económico debido a la escasez de brazos requerida para la expansión agro exportadora, producto de la poca población. Los salarios tendieron a la alza, el salario mensual de un peón se elevó de 8 a 15 pesos entre 1853 y 1856 y el proceso de colonización agrícola hacia el oeste del Valle Central se desaceleró. La muerte del padre o la madre, en una economía basada en unidades familiares con leyes de herencia orientadas a fragmentar el patrimonio, propició este proceso, el cual conllevaba la apertura de mortual y el pago de deudas. Algunos campesinos debieron rematar sus propiedades o parte de

devociones generadas alrededor de la guerra contra los filibusteros en Nicaragua y Costa Rica, véase también la investigación de la historiadora Carmela Velásquez sobre "La Iglesia católica en Costa Rica y Nicaragua y la Campaña Nacional 1856-1857”, contenida en la Memoria del simposio internacional sobre El filibusterismo y el Destino Manifiesto en las Américas, realizado en la sede de la Universidad de Costa Rica en Liberia, Guanacaste, mayo del 2007. 
las mismas para cancelar las deudas. ${ }^{113}$ En consecuencia, la vida de muchos costarricenses y del Estado quedó marcada por la crisis económica y fiscal.

La epidemia del cólera dejó muchas lecciones en el campo de la intervención estatal orientada a la salud, especialmente en lo concerniente al control de las epidemias, que se fueron estableciendo en los años posteriores, conforme las condiciones políticas producto de la Campaña Nacional 1856-1857 y los conflictos entre sectores de la burguesía por el control del Estado tendieron a normalizarse. Entre ellas la mejora de los hospitales San Juan de Dios en San José y San Rafael en Puntarenas, el establecimiento de medidas preventivas en los puertos, pueblos y ciudades, la creación de una estructura organizativa para a los médicos de pueblo ${ }^{114}$ y la educación sanitaria en las escuelas.

Las poblaciones de centros urbanos, villas y pueblos fueron tomando mayor conciencia de la importancia del agua como vehículo transmisor de enfermedades y de la necesidad de construir cañerías. Sin embargo, los gastos de la guerra y la epidemia dejaron exhausto el erario, y por consiguiente su concreción fue lenta, pese a las constantes demandas en ese sentido.

La creación del Protomedicato fue fundamental en varios sentidos, tal y como lo hemos señalado, en párrafos anteriores. Aunque su aparición es tardía en Costa Rica, ya que su origen es colonial, se tornó crucial en la conformación de un campo médico, en la obtención del monopolio cognitivo del arte de curar por parte de estos, por encima de todas las otras profesiones en el campo de la salud y los diferentes tipos de curadores. Fue el inicio de una sólida alianza entre la elite médica y las autoridades estatales con el fin de apoyarse mutuamente. Los médicos se aliaron al Estado para garantizar su mercado de trabajo, tanto la clientela particular, muy reducida en ese entonces por la poca aceptación entre la población, como a nivel del Estado, en instituciones y programas. Por su parte, el Estado requirió de ellos para su consolidación institucional, para darle una dirección "científica" a la sociedad, para civilizar e higienizar a los costarricenses.

Desde el Protomedicato, los médicos se dirigieron también a las elites de la sociedad, demandando un creciente papel social para ellos como grupo profesional y para sus instituciones, esta y otras que fueron creando o desarrollando, como la Facultad de Medicina, el Hospital San Juan de Dios, las revistas médicas, la sub secretaría de Salud y otras. Esto lo consiguieron de la

113 Molina, Iván. La Campaña Nacional (1856-1857), 43-49.

114 La legislación sobre los médicos de pueblo continuó recibiendo reformas para promover un mayor impacto social durante el siglo XIX, en 1865y 1894. 
misma manera en que González Leandri, lo ha estudiado para el caso argentino, promoviendo una imagen pública del médico, asociada a la caridad y a la actividad científica. Los médicos, pasaron a controlar un concepto que resultó ser clave para la supervivencia social: la higiene. ${ }^{115}$ Primero, bajo concepciones clásicas y después de la revolución bacteriológica, bajo nuevas concepciones.

Además, es probable, que en vista de la recurrencia de las epidemias, a las cuales se les atribuían orígenes parecidos, relacionados con la teoría de los miasmas, por parte del pequeño sector de la sociedad integrado por las autoridades políticas, los letrados y los médicos, un sector de la población, más urbano y con mayor nivel de escolarización, comenzara a desarrollar una cultura para prevenirlas.

La religiosidad católica profesada por los costarricenses, la mayoría campesinos, se avivó en el desarrollo de la epidemia. Para esto contribuyeron sus concepciones sobre el origen de las enfermedades, las visiones, ritos, discursos y simbolismo religioso promovidas por los sacerdotes y la jerarquía eclesiástica y la impotencia y vulnerabilidad frente a ellas. Por eso estamos seguros de que "los tiempos del cólera” marcaron la vida de los costarricenses en muchos aspectos.

115 Al respecto es sumamente sugerente el trabajo de González Leandro, Ricardo Curar, persuadir, gobernar: 58-59. 